\title{
Catalytic Enantioselective Addition of Organozirconium Reagents to Aldehydes
}

\author{
Ricard Solà ${ }^{1}$, Marcos Veguillas ${ }^{1}$ (D), María José González-Soria ${ }^{1}$, Nicholas Carter ${ }^{1}$, \\ M. Angeles Fernández-Ibáñez ${ }^{2, *}$ and Beatriz Maciá ${ }^{1, * \text { (D) }}$ \\ 1 Division of Chemistry \& Environmental Science, Manchester Metropolitan University, Oxford Road, \\ Manchester M1 5GD, UK; rsolamestres@gmail.com (R.S.); marcos_veguillas@yahoo.es (M.V.); \\ mariajo.gonzalez.s@gmail.com (M.J.G.-S.); ncarter1@sheffield.ac.uk (N.C.) \\ 2 Van 't Hoff Institute for Molecular Sciences, Science Park 904, Amsterdam 1090 GS, The Netherlands \\ * Correspondence: M.A.FernandezIbanez@uva.nl (M.A.F.-I.); b.macia-ruiz@mmu.ac.uk (B.M.); \\ Tel.: +31-(0)205-258-753 (M.A.F.-I.); Tel.: +44-(0)161-247-1416 (B.M.)
}

Received: 6 April 2018; Accepted: 17 April 2018; Published: 20 April 2018

\begin{abstract}
A catalytic enantioselective addition reaction of alkylzirconium species to aromatic aldehydes is reported. The reaction, facilitated by a chiral nonracemic diol ligand complex with $\mathrm{Ti}\left(\mathrm{O}^{i} \mathrm{Pr}\right)_{4}$, proceeds under mild and convenient conditions, and no premade organometallic reagents are required since the alkylzirconium nucleophiles are generated in situ by hydrozirconation of alkenes with the Schwartz reagent. The methodology is compatible with functionalized nucleophiles and a broad range of aromatic aldehydes.
\end{abstract}

Keywords: alkenes; asymmetric catalysis; titanium; addition to aldehydes; Schwartz reagent

\section{Introduction}

Chiral alcohol-containing molecules are recurrent, high-value targets in the pharmaceutical, agricultural, and material science sectors, amongst others; the development of efficient methods for their construction remains a high priority in organic synthesis [1].

The catalytic enantioselective 1,2-addition reaction of organometallic reagents to carbonyl compounds is one of the most efficient approaches to chiral alcohols. This transformation has been extensively studied with dialkylzinc [2-17] and trialkylaluminium [18-20] reagents; more recently, excellent results with Grignard [21-35] and organolithium [36-38] reagents have also been reported. The high reactivity and sometimes pyrophoric character of these premade, non-stabilized organometallic nucleophiles, however, restricts the implementation of these methodologies in industrial processes and large-scale reactions [39]. Other complicating factors are the frequent requirement for cryogenic temperatures (necessary in order to obtain high levels of enantioselectivity but often prohibitively expensive at large scale) and incompatibilities with several functional groups $[40,41]$. The use of less reactive nucleophiles circumvents some of these issues. Organozirconium reagents [42-48] are relatively inert toward carbonyl compounds [49], but the use of catalysts or a stoichiometric mediator [50-60] enables the nucleophilic attack and subsequent carbon-carbon bond formation. Thus, in the presence of $\mathrm{Ag}(\mathrm{I}), \mathrm{ZnBr}_{2}, \mathrm{or}_{\mathrm{Me}} \mathrm{Zn}$, organozirconium reagents can readily be added to aldehydes [61-68], ketones [69,70], and also enones [71-74], epoxides [75], and isocyanates [76], although enantioselective protocols have been rare so far [77-92]. In 1994, Wipf reported [63,64] a high-yielding protocol for the in situ transmetalation of alkenylzirconocenes to alkenylzinc species with stoichiometric amounts of $\mathrm{Me}_{2} \mathrm{Zn}$, and succeeded in developing a catalytic asymmetric methodology for their subsequent additions to aldehydes [93,94]. A similar strategy was adopted by Walsh et al. for the addition of alkenylzirconocenes to ketones 
catalysed by a bis-(sulphonamide) diol ligand in the presence of stoichiometric $\mathrm{Ti}\left(\mathrm{O}^{i} \mathrm{Pr}\right)_{4}$ [95]. We are not aware, however, of any successful report addressing the catalytic asymmetric addition of alkylzirconocene nucleophiles to carbonyls $[14,31,96]$.

The use of alkylzirconocene reagents in synthesis is greatly facilitated by their ready accessibility via (in situ) hydrozirconation of alkenes using Schwartz reagent [97-99] ( $\left.\mathrm{Cp}_{2} \mathrm{ZrHCl}\right)$. This offers two key advantages: (i) alkenes, as starting materials, are inexpensive, abundant, and easy to handle [100]; (ii) hydrozirconation reaction conditions are compatible with many functional groups [101].

Here, we report the first enantioselective catalytic 1,2-addition of alkylzirconium reagents to aldehydes, based on a titanium-Ar-BINMOL complex. This methodology affords high levels of enantioselectivity at industrially relevant temperatures and the reaction tolerates functional groups that are not compatible with other organometallic reagents.

\section{Results and Discussion}

Provided with both axial and tetrahedral chirality, 1,1-binaphthalene-2- $\alpha$-arylmethan-2-ols (Ar-BINMOLs) — developed by Kiyooka, Lai, and Xu [102-105] — have recently emerged as very efficient ligands for the titanium-assisted catalytic addition of organometallic reagents to carbonyl compounds $[21,23,30,36,37]$. Here, we started our investigations by evaluating the use of the very versatile Ph-BINMOL [23,102-105] ligand in the addition of 1-hexene to benzaldehyde (Table 1). Following known procedures [97-99], the treatment of 1-hexene with 2.0 eq. of Schwartz reagent $\left(\mathrm{Cp}_{2} \mathrm{ZrHCl}\right)$ provided the corresponding organozirconium reagent, which was then added to a solution of benzaldehyde (1.0 eq., $0.125 \mathrm{M}$ ) and Ph-BINMOL (20 mol\%) in DCM at RT (Table 1). As expected, very low conversion to the desired alcohol 3aa was observed (13\%, entry 1$)$. Under similar conditions ( $0.125 \mathrm{M}$ in benzaldehyde), the reaction was attempted in the presence of 2.5-2.8 eq. of various additives (AgOTs, $\mathrm{Ti}\left(\mathrm{O}^{i} \mathrm{Pr}\right)_{4}, \mathrm{TiCl}\left(\mathrm{O}^{i} \mathrm{Pr}\right)_{3}, \mathrm{CuI}$, and $\left.\mathrm{Et}_{2} \mathrm{Zn}\right)$ in DCM at RT. No conversion was observed except in the presence of 2.0 eq. of $\mathrm{Et}_{2} \mathrm{Zn}$ (19\% conversion to racemic 3aa; entry 2). In accordance with Srebnik's observations [62], more concentrated reaction conditions ( $0.5 \mathrm{M}$ benzaldehyde in DCM) provided higher conversion to the desired product 3aa (44\%, entry 3$)$, although the enantioselectivity of the process remained zero.

An extensive screening of zinc additives revealed that the use of $\mathrm{ZnBr}_{2}$ (0.5 eq.) in combination with $\mathrm{Ti}\left(\mathrm{O}^{i} \mathrm{Pr}\right)_{4}$ (1.5 eq.) provides the desired alcohol 3aa in $83 \%$ isolated yield and $80 \%$ ee, using only 1.4 eq. of the alkene and 1.2 eq. of the Schwartz reagent, in DCM ( $0.5 \mathrm{M}$ benzaldehyde) at RT (entry 4$)$. It is important to mention that the reaction proved to be very sensitive to the concentration and no conversion was observed under more diluted conditions ( $0.11 \mathrm{M}$ benzaldehyde in DCM, entry 5$)$.

Working at the preferred $0.5 \mathrm{M}$ concentration of substrate in DCM, variation of the titanium source $\left(\mathrm{TiCl}\left(\mathrm{O}^{i} \mathrm{Pr}\right)_{3}\right.$ instead of $\left.\mathrm{Ti}\left(\mathrm{O}^{i} \mathrm{Pr}\right)_{4}\right)$, however, resulted in increased reduction of the starting material to phenylmethanol, whilst the desired product 3 aa was obtained in a racemic form (entry 6). Co-solvents-tert-butylmethyl ether, THF, toluene, and diethyl ether-were also assayed in combination with DCM, which we found to be optimal for the hydrozirconation step; all attempts provided lower conversion and enantioselectivity than the use of DCM alone.

Changes in the titanium loading (entries 7-8) or the amount of $\mathrm{ZnBr}_{2}$ (entries 9-10), only afforded increased amounts of the undesired reduced product and lower enantioselectivities. To our surprise, when the reaction was carried out at lower temperature $\left(0{ }^{\circ} \mathrm{C}\right.$, overnight $)$, lower enantioselectivity was observed ( $35 \% e e$, entry 11$)$, whilst higher temperatures $\left(35^{\circ} \mathrm{C}\right)$ provided slightly higher enantioselectivity than RT ( $82 \%$ ee, compare entries 12 and 4), but lower conversion (51\%). By way of comparison, the reaction was assessed using ( $R$ )-BINOL (20 $\mathrm{mol} \%$ ) as ligand; $9 \%$ conversion to the desired product 3aa was obtained in $56 \%$ ee (entry 13 ). 
Table 1. Optimisation of reaction conditions for the addition of 1-hexene (2a) to benzaldehyde (1a) ${ }^{a}$.

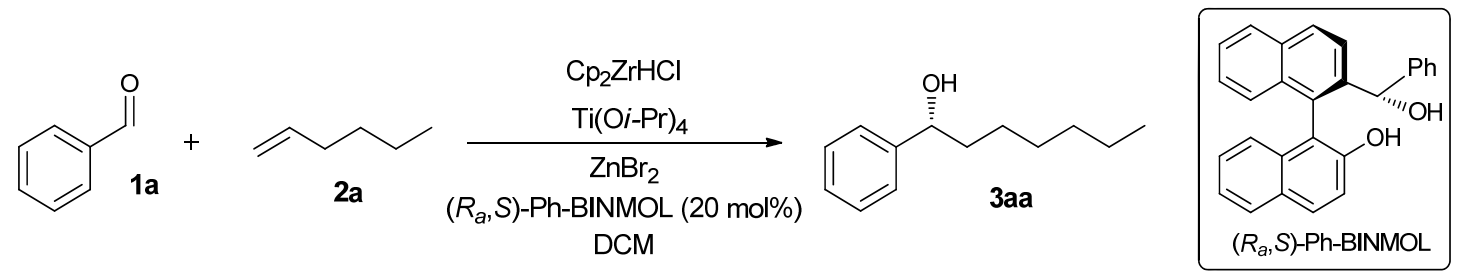

\begin{tabular}{|c|c|c|c|c|c|c|c|}
\hline Entry & $\begin{array}{c}\mathrm{Cp}_{2} \mathrm{ZrHCl} \\
\text { (eq.) }\end{array}$ & $\begin{array}{l}\text { 1-hexene } \\
\text { (eq.) }\end{array}$ & $\begin{array}{c}\mathrm{Ti}\left(\mathrm{O}^{i} \mathrm{Pr}\right)_{4} \\
\quad \text { (eq.) }\end{array}$ & $\begin{array}{c}\mathrm{ZnBr}_{2} \\
\text { (eq.) }\end{array}$ & Conv. $(\%)^{b}$ & $\begin{array}{c}\text { Undesired } \\
\text { Phenylmethanol (\%) }\end{array}$ & $e e(\%)$ \\
\hline $1^{d}$ & 2 & 2 & - & - & 13 & 0 & 0 \\
\hline 3 & 2 & 2 & - & $-\mathrm{e}$ & 44 & 0. & \\
\hline 4 & 1.2 & 1.4 & 1.5 & 0.5 & n.d. $(83)^{f}$ & 10 & 80 \\
\hline $5 \mathrm{~g}$ & 1.2 & 1.4 & 1.5 & 0.5 & 1 & n.d. & 0 \\
\hline 8 & 1.2 & 1.4 & 2.0 & 0.5 & 5 & 89 & 62 \\
\hline 9 & 1.2 & 1.4 & 1.5 & 0.2 & 18 & 73 & 80 \\
\hline 10 & 1.2 & 1.4 & 1.5 & 0.7 & 20 & 74 & 66 \\
\hline $11^{\mathrm{i}}$ & 1.2 & 1.4 & 1.5 & 0.5 & 6 & 67 & 35 \\
\hline $12^{\mathrm{j}}$ & 1.2 & 1.4 & 1.5 & 0.5 & 51 & 36 & 82 \\
\hline
\end{tabular}

${ }^{a}$ Reaction conditions: 1a $(0.15 \mathrm{mmol}, 1.0$ eq. $),\left(R_{\mathrm{a}}, S\right)$-Ph-BINMOL ( 0.2 eq. $)$, $\mathrm{Ti}\left(\mathrm{O}^{i} \mathrm{Pr}\right)_{4}$ (1.5 eq. $)$, DCM $(0.5 \mathrm{M})$, room temperature, overnight. ${ }^{\mathrm{b}}$ Determined by CG-MS. ${ }^{\mathrm{c}}$ Determined by Chiral GC (see supplementary material for further details). ${ }^{\mathrm{d}} 0.125 \mathrm{M}$ in benzaldehyde. ${ }^{\mathrm{e}}$ Reaction carried out with $\mathrm{Et}_{2} \mathrm{Zn}$ instead of $\mathrm{ZnBr}_{2} .{ }^{\mathrm{f}}$ Isolated yield after flash chromatography. ${ }^{g} 0.11 \mathrm{M} 1 \mathrm{a}$ in DCM. ${ }^{\mathrm{h}}$ Reaction carried out with 1.5 eq. of $\mathrm{TiCl}\left(\mathrm{O}^{i} \mathrm{Pr}\right)_{3}$ instead of $\mathrm{Ti}\left(\mathrm{O}^{i} \mathrm{Pr}\right)_{4}$. ${ }^{\mathrm{i}}$ Reaction carried out at $0{ }^{\circ} \mathrm{C} .{ }^{\mathrm{j}}$ Reaction carried out at $35^{\circ} \mathrm{C} .{ }^{\mathrm{k}}(R)$-BINOL $(20 \mathrm{~mol} \%)$ used as ligand. ${ }^{1}$ Configuration determined based on the optical rotation, by comparison with literature.

Lowering the amounts of the Schwartz reagent and the alkene provided higher enantioselectivity (90\%) but lower conversion to the desired 3aa, due to a substantial increase in the reduction by-product (entry 14). Fortunately, improved results were obtained with increased amounts of Schwartz reagent and the alkene, and, after fine adjustments, $99 \%$ conversion and $93 \%$ ee could be reached in $5 \mathrm{~h}$ when 2.0 eq. of Schwartz reagent were used in combination with 2.2 eq. of alkene in DCM at $35^{\circ} \mathrm{C}$ (entry 15).

Regarding the mechanism of the addition reaction, a number of pathways are possible. The transmetallation of the organozirconium reagent with $\mathrm{ZnBr}_{2}$ [106-108], followed by second transmetallation with the appropriate organotitanium species is a very plausible route [97-99]. However, the activation of aldehydes by complexation with zinc halides [109] is a well-known process that cannot be discarded at this stage of our investigations. It is worth pointing out the versatility of Ar-BINMOL ligands, in particular the simple and readily available Ph-BINMOL, which is able to catalyse the carbonyl addition of a broad spectrum of organometallic reagents, including organozinc [110], organomagnesium [21,23,30], organolithium [36-38], organoaluminum [20], organotitanium [111], and, now, organozirconium reagents. As far as we know, this catalytic system allows the broadest variety of organometallic reagents in enantioselective 1,2-addition to carbonyl groups.

With the optimised conditions in hand, we tested the scope of the reaction with different aromatic aldehydes (Table 2). Thus, the reaction of 1-hexene (2a) with $p$-tolualdehyde afforded product $\mathbf{3} \mathbf{b a}$ with good yield (74\%) and excellent enantioselectivity (91\%, entry 1$)$. In the case of $m$ - and $o$-tolualdehyde (entries 2 and 3), where the methyl substituent in the aromatic ring is closer to the reactive site, higher percentages of the corresponding aryl methanol (reduction of the aldehyde) and dehydration products 4 (Figure 1) were obtained, as well as lower enantioselectivity ( $89 \%$ and $76 \%$, respectively); this is probably due to increased steric hindrance close to the carbonyl group. The reaction with $p$-bromo and $p$-chlorobenzaldehyde afforded moderated yields (56\% and 59\%) and excellent enantioselectivities 
(91\% and 90\%, entries 4 and 5, respectively). The use of $p$-acetylbenzaldehyde as starting material (entry 6), provided the corresponding alcohol 3ga in excellent enantioselectivity (94\%) but lower yield (32\%). This is probably due to the reduction of the acetyl group by $\beta$-hydride transfer from the organometallic reagent (by-product 5, Figure 1). Gratifyingly, the methodology proved to be compatible with other functional groups such as $p$-CN (entry 7) and $p-\mathrm{CF}_{3}$ (entry 8), leading to good yield $(55-58 \%)$ and high enantioselectivity $(87 \% e e)$. Unfortunately, aliphatic and $\alpha, \beta$-unsaturated aldehydes gave very low conversions under these reaction conditions.

Table 2. Enantioselective catalysed addition of 1-hexene (2a) to aromatic aldehydes-Scope of the reaction ${ }^{\mathrm{a}}$.

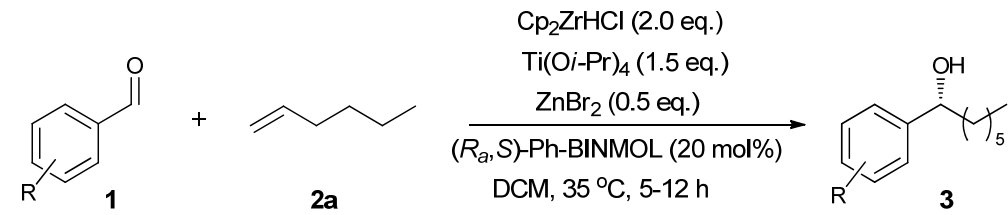

$$
\begin{gathered}
0.15 \mathrm{mmol} \\
0.375 \mathrm{M} \text { in DCM }
\end{gathered}
$$

\begin{tabular}{|c|c|c|c|c|c|}
\hline Entry & Product & Conv. $(\%)^{b}$ & Undesired Arylmethanol (\%) $b$ & Yield (\%) ${ }^{c}$ & $e e(\%)^{\mathrm{d}}$ \\
\hline 1 & & 94 & 6 & 74 & $91(R)$ \\
\hline 2 & & 77 & $15^{\mathrm{e}}$ & 54 & $89(R)$ \\
\hline 3 & & 54 & $28^{f}$ & 49 & $76(R)$ \\
\hline 4 & & 87 & 10 & 56 & $91(R)$ \\
\hline $5^{g}$ & & 92 & 6 & 59 & $90(R)$ \\
\hline 6 & $3 g$ & 76 & $4^{\mathrm{h}}$ & 32 & $94(R)$ \\
\hline $7^{f}$ & & 81 & 19 & 58 & $87(R)$ \\
\hline 8 & & 69 & 28 & 55 & $87^{\mathrm{i}}(R)$ \\
\hline
\end{tabular}

a Reaction conditions: 3 (0.15 mmol, 1.0 eq.), ( $\left.R_{\mathrm{a}}, S\right)$-Ph-BINMOL (0.2 eq.), Ti(O $\left.{ }^{i} \mathrm{Pr}\right)_{4}(1.5$ eq.), 1-hexene (2.2 eq.), $\mathrm{Cp}_{2} \mathrm{ZrHCl}$ (2.0 eq.), $\mathrm{ZnBr}_{2}$ (0.5 eq.), DCM (0.375 M), $35^{\circ} \mathrm{C}, 5-12$ h. ${ }^{\mathrm{b}}$ Determined by GC-MS. ${ }^{\mathrm{c}}$ Isolated yield after flash chromatography. ${ }^{\mathrm{d}}$ Determined by Chiral GC. Configuration based on literature data (see supplementary material for details). e $8 \%$ of dehydration product 4 was observed by GC-MS. ${ }^{\mathrm{f}} 18 \%$ of dehydration product 4 was observed by GC-MS. g The reaction was carried out in DCM (0.3 M). ${ }^{\mathrm{h}} 19 \%$ of 5 was observed by GC-MS.

${ }^{\mathrm{i}}$ Determined on the corresponding acetate derivative (see supplementary material for further details). 

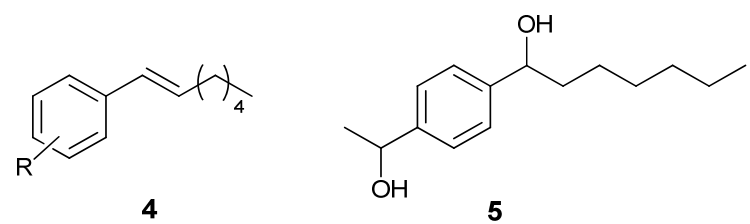

Figure 1. By-products of the reaction.

Next, we tested the scope of the reaction with different alkenes (Table 3). Thus, the reaction of 4-phenyl-1-butene (2b) with benzaldehyde (1a) provided the corresponding alcohol 3ab in excellent yield $(93 \%)$ and good enantioselectivity $(77 \%$ ee, entry 1$)$. The methodology is also compatible with functionalised alkenes. The reaction of benzaldehyde with 4-[(tert-butyldimethylsilyl)oxy]-1-butene (2c) led to the desired alcohol 3ac in moderate yield ( $42 \%$ ) but good enantioselectivity ( $88 \%$ ee, entry 2$)$. Similar results were obtained when 4-halo-1-butenes $\mathbf{2 d}$ and $\mathbf{2 e}$ were used as nucleophiles (entries 3 and 4), providing 3ad and 3ae in moderate yields and 85 and $74 \% e e$, respectively. The use of 5-bromopent-1-ene (2f) provided 3 af in $31 \%$ yield and $81 \%$ ee.

Table 3. Enantioselective catalysed addition of alkenes to benzaldehyde-Scope of the reaction ${ }^{\text {a }}$.

\begin{tabular}{llll}
\hline Entry & Conv. (\%) ${ }^{\mathbf{b}}$ & Yield (\%) $^{\mathbf{c}}$ & $\boldsymbol{e e ~ ( \% )}^{\mathbf{d}}$ \\
\hline
\end{tabular}

${ }^{a}$ Reaction conditions: 1a $\left(0.15 \mathrm{mmol}, 1.0\right.$ eq.), $\left(R_{\mathrm{a}}, S\right)-\mathrm{Ph}-\mathrm{BINMOL}\left(0.2\right.$ eq.), $\mathrm{Ti}\left(\mathrm{O}^{i} \mathrm{Pr}\right)_{4}$ (1.5 eq.), 2 (2.2 eq.), $\mathrm{Cp}_{2} \mathrm{ZrHCl}$ (2.0 eq.), $\mathrm{ZnBr}_{2}$ (0.5 eq.), DCM $(0.375 \mathrm{M}), 35{ }^{\circ} \mathrm{C}, 5-12 \mathrm{~h} .{ }^{\mathrm{b}}$ Determined by GC-MS. ${ }^{\mathrm{c}}$ Isolated yield after flash chromatography. ${ }^{\mathrm{d}}$ Determined by Chiral GC. Configuration based on literature data (see supplementary material for details). ${ }^{e}$ Reaction carried out with 3.0 eq. of 2 and 2.8 eq. of $\mathrm{Cp}_{2} \mathrm{ZrHCl} .{ }^{\mathrm{f}} 15 \%$ of dehydration product 4 was observed by GC-MS. ${ }^{g}$ Determined on the corresponding cyclised derivative 6 (see supplementary material for details).

As an application of this methodology, product 3ad was transformed into its corresponding tetrahydropyran adduct 6 . Tetrahydropyran rings are very important structural moieties, which are present in a large variety of natural products such as polyether antibiotics and marine macrocycles [112-116]. Additionally, they are also employed in the perfume industry or as flavouring ingredients in the food industry [117].

Thus, following a straightforward procedure [118], alcohol 3ad was dissolved in dry THF and treated with 2 eq. of $\mathrm{KO}^{t} \mathrm{Bu}$ at RT. Tetrahydropyran 6 was obtained in $84 \%$ yield and $85 \%$ ee after purification by column chromatography (Scheme 1). It is worth pointing out that no racemization occurs during the cyclization [119]. This strategy constitutes a novel and straightforward method for 
the synthesis of chiral tetrahydropyran derivatives via an enantioselective 1,2-addition of an alkene to a carbonyl followed by an intramolecular $\mathrm{SN}_{2}$ reaction.

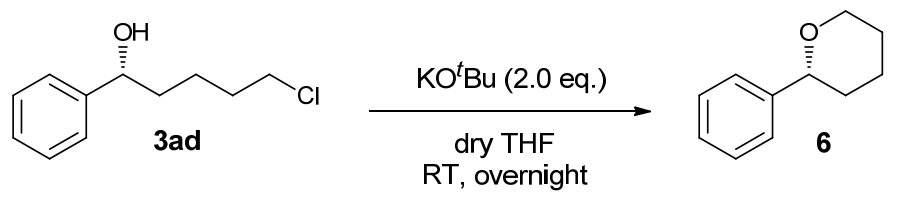

Scheme 1. Formation of the chiral tetrahydropyran 6 from chiral chloroalcohol 3ad.

\section{Materials and Methods}

General procedure for the catalytic enantioselective 1,2-addition of alkenes to aldehydes: To a stirred suspension of $\mathrm{Cp}_{2} \mathrm{ZrHCl}(77 \mathrm{mg}, 0.3 \mathrm{mmol}, 2.0$ eq.) in dry DCM (0.3 mL) at RT, the corresponding alkene ( $0.33 \mathrm{mmol}, 2.2 \mathrm{eq}$.) was added dropwise and the solution was stirred at RT for $30 \mathrm{~min}$. The mixture turned into a clear yellow solution, which indicated the successful formation of the organozirconium reagent. Next, flamed-dried $\mathrm{ZnBr}_{2}(0.075 \mathrm{mmol}, 0.5$ eq.) was added into the solution and the mixture was stirred at RT for $2 \mathrm{~min}$. Subsequently, a solution of $\mathrm{Ti}\left(\mathrm{O}^{i} \mathrm{Pr}\right)_{4}(0.225 \mathrm{mmol}, 1.5 \mathrm{eq}$.) and $\left(R_{\mathrm{a}}, S\right)$-Ph-BINMOL $(20 \mathrm{~mol} \%)$ in dry DCM $(0.1 \mathrm{~mL})$ was added and stirred for further $2 \mathrm{~min}$ at RT. Finally, the aldehyde $(0.15 \mathrm{mmol})$ was added and the solution was stirred at $35^{\circ} \mathrm{C}$ for $3-18 \mathrm{~h}$ (reaction was monitored by TLC). (Note that liquid aldehydes were previously distilled before its addition whilst solid aldehydes were dissolved in dry DCM ( 0.1 or $0.2 \mathrm{~mL}$ depending on its solubility) and added to the solution.) The reaction was quenched by the addition of water $(1 \mathrm{~mL})$. The layers were separated, and the aqueous layer was extracted with $\mathrm{Et}_{2} \mathrm{O}(3 \times 10 \mathrm{~mL})$. The combined organic layers were dried with anhydrous $\mathrm{MgSO}_{4}$, filtered, and concentrated under vacuum. The crude reaction product was purified by flash silica gel chromatography.

\section{Conclusions}

In conclusion, we have developed a new and efficient procedure for the titanium-assisted catalytic asymmetric addition of alkylzirconium reagents to aromatic aldehydes, based on the use of a readily available Ar-BINMOL ligand and $\mathrm{ZnBr}_{2}$. The alkylzirconium nucleophiles are generated in situ by hydrozirconation of alkenes with Schwartz reagent, thus avoiding the use of premade organometallic reagents. The reaction-which proceeds under mild conditions and industrially relevant temperatures-allows the synthesis of the corresponding chiral secondary alcohols in moderate to good yields (32-93\%) and good to excellent enantioselectivities (76-91\% ee). It is worth mentioning that the methodology is compatible with the presence of several functional groups in both the aldehyde (including halogens, ketone, cyano, and trifluoromethyl) and the alkene (including halogens and TBS protected alcohol). The usefulness of this novel method has been demonstrated with the enantioselective synthesis of a chiral tetrahydropyran by a subsequent intramolecular cyclization on a functionalised addition product.

Supplementary Materials: Experimental methods and spectroscopic data for new compounds are available online.

Acknowledgments: B.M. thanks the European Commission for a Marie Curie Career Integration Grant, the EPSRC for a First Grant and the R.S. for a travel grant. G.P. Howell is thanked for helpful comments on the manuscript.

Author Contributions: R.S., M.V., B.M., and M.A.F.-I. conceived and designed the experiments; R.S., M.V., M.J.G.-S., and N.C. performed the experiments and analyzed the data; B.M. and M.A.F.-I. contributed reagents/materials/analysis tools and wrote the paper.

Conflicts of Interest: The authors declare no conflict of interest. 


\section{References}

1. Hanessian, S. Total Synthesis of Natural Products: The Chiron Approach; Pergamon Press: Oxford, UK, 1983; Volume XVIII, 291p, ISBN 0-08-030715-9.

2. Wang, M.C.; Zhang, Q.-J.; Li, G.-W.; Liu, Z.-K. Highly enantioselective addition of dimethylzinc to arylaldehydes catalyzed by (2S)-1-ferrocenyl-methylaziridin-2-yl(diphenyl)methanol. Tetrahedron Asymmetry 2009, 20, 288-292. [CrossRef]

3. Sokeirik, Y.S.; Mori, H.; Omote, M.; Sato, K.; Tarui, A.; Kumadaki, I.; Ando, A. Synthesis of a Fluorous Ligand and its Application for Asymmetric Addition of Dimethylzinc to Aldehydes. Org. Lett. 2007, 9, 1927-1929. [CrossRef] [PubMed]

4. Cozzi, P.G.; Kotrusz, P. Highly Enantioselective Addition of $\mathrm{Me}_{2} \mathrm{Zn}$ to Aldehydes Catalyzed by $\mathrm{ClCr}(\mathrm{Salen})$. J. Am. Chem. Soc. 2006, 128, 4940-4941. [CrossRef] [PubMed]

5. Mandal, A.K.; Schneekloth, J., Jr.; Kuramochi, K.; Crews, C.M. Synthetic Studies on Amphidinolide B1. Org. Lett. 2006, 8, 427-430. [CrossRef] [PubMed]

6. Blay, G.; Fernández, I.; Hernández-Olmos, V.; Marco-Aleixandre, A.; Pedro, J.R. Enantioselective addition of dimethylzinc to aldehydes catalyzed by $N$-substituted mandelamide-Ti(IV) complexes. Tetrahedron Asymmetry 2005, 16, 1953-1958. [CrossRef]

7. Kobayashi, Y.; Fukuda, A.; Kimachi, T.; Juichi, M.; Takemoto, Y. Asymmetric synthetic study of macrolactin analogues. Tetrahedron 2005, 61, 2607-2622. [CrossRef]

8. García-Delgado, N.; Fontes, M.; Pericás, M.A.; Riera, A.; Verdaguer, X. Enantioselective addition of dimethylzinc to aldehydes: Assessment of optimal $N, N$-substitution for 2-dialkylamino-1,1,2triphenylethanol ligands. Tetrahedron Asymmetry 2004, 15, 2085-2090. [CrossRef]

9. Sprout, C.M.; Richmond, M.L.; Seto, C.T. Solid-Phase synthesis of chiral N-acylethylenediamines and their use as ligands for the asymmetric addition of alkylzinc and alkenylzinc reagents to aldehydes. J. Org. Chem. 2004, 69, 6666-6673. [CrossRef] [PubMed]

10. Cozzi, P.G.; Locatelli, M. Catalytic Enantioselective Addition of $\mathrm{Me}_{2} \mathrm{Zn}$ to Aromatic Aldehydes Promoted by New Modular Thiophene-Oxazoline Ligands. Lett. Org. Chem. 2004, 1, 208-211. [CrossRef]

11. Jones, G.B.; Huber, R.S.; Chapman, B.J. Catalytic enantioselective synthesis of macrolides via asymmetric alkylation. Tetrahedron: Asymmetry 1997, 8, 1797-1809. [CrossRef]

12. Kitamura, M.; Suga, S.; Kawai, K.; Noyori, R. Catalytic asymmetric induction. Highly enantioselective addition of dialkylzincs to aldehydes. J. Am. Chem. Soc. 1986, 108, 6071-6072. [CrossRef] [PubMed]

13. Binder, C.M.; Singaram, B. Asymmetric addition of diorganozinc reagents to aldehydes and ketones. Org. Prep. Proced. Int. 2011, 43, 139-208. [CrossRef]

14. Ramón, D.J.; Yus, M. In the arena of enantioselective synthesis, titanium complexes wear the laurel wreath. Chem. Rev. 2006, 106, 2126-2208. [CrossRef] [PubMed]

15. Yus, M.; Ramón, D.J. Enantioselective addition of organozinc reagents to carbonyl compounds. Pure Appl. Chem. 2005, 77, 2111-2119. [CrossRef]

16. Yus, M.; Ramón, D.J. Recent developments in the enantioselective 1,2-addition of organometallic reagents to carbonylic compounds. Recent Res. Dev. Org. Chem. 2002, 6, 297-378.

17. Pu, L.; Yu, H.-B. Catalytic asymmetric organozinc additions to carbonyl compounds. Chem. Rev. 2001, 101, 757-824. [CrossRef] [PubMed]

18. Mata, Y.; Dièguez, M.; Pàmies, O.; Woodward, S. Screening of a Modular Sugar-Based Phosphite Ligand Library in the Asymmetric Nickel-Catalyzed Trialkylaluminum Addition to Aldehydes. J. Org. Chem. 2006, 71, 8159-8165. [CrossRef] [PubMed]

19. Biswas, K.; Prieto, O.; Goldsmith, P.; Woodward, S. Remarkably Stable $\left(\mathrm{Me}_{3} \mathrm{Al}\right)_{2}$. DABCO and Stereoselective Nickel-Catalyzed $\mathrm{AlR}_{3}(\mathrm{R}=\mathrm{Me}$, Et) Additions to Aldehydes. Angew. Chem. Int. Ed. 2005, 44, 2232-2234. [CrossRef] [PubMed]

20. Fernández-Mateos, E.; Maciá, B.; Yus, M. Catalytic enantioselective addition of organoaluminum reagents to aldehydes. Tetrahedron Asymmetry 2012, 23, 789-794. [CrossRef]

21. Fernández-Mateos, E.; Maciá, B.; Yus, M. Catalytic Enantioselective Addition of Alkyl Grignard Reagents to Aliphatic Aldehydes. Adv. Synth. Catal. 2013, 355, 1249-1254. [CrossRef] 
22. Zheng, L.-S.; Jiang, K.-Z.; Deng, Y.; Bai, X.-F.; Gao, G.; Gu, F.-L.; Xu, L.-W. Synthesis of Ar-BINMOL Ligands by [1,2]-Wittig Rearrangement to Probe Their Catalytic Activity in 1,2-Addition Reactions of Aldehydes with Grignard Reagents. Eur. J. Org. Chem. 2013, 4, 748-755. [CrossRef]

23. Fernández-Mateos, E.; Maciá, B.; Ramón, D.J.; Yus, M. Catalytic Enantioselective Addition of MeMgBr and Other Grignard Reagents to Aldehydes. Eur. J. Org. Chem. 2011, 2011, 6851-6855. [CrossRef]

24. Itakura, D.; Harada, T. Catalytic Enantioselective Arylation of Aldehydes by Using Functionalized Grignard Reagents Generated from Aryl Bromides. Synlett 2011, 2011, 2875-2879. [CrossRef]

25. Liu, Y.; Da, C.-S.; Yu, S.-L.; Yin, X.-G.; Wang, J.-R.; Fan, X.-Y.; Li, W.-P.; Wang, R. Catalytic Highly Enantioselective Alkylation of Aldehydes with Deactivated Grignard Reagents and Synthesis of Bioactive Intermediate Secondary Arylpropanols. J. Org. Chem. 2010, 75, 6869-6878. [CrossRef] [PubMed]

26. Fan, X.-Y.; Yang, Y.-X.; Zhuo, F.-F.; Yu, S.-L.; Li, X.; Guo, Q.-P.; Du, Z.-X.; Da, C.-S. AlCl 3 and BDMAEE: A Pair of Potent Reactive Regulators of Aryl Grignard Reagents and Highly Catalytic Asymmetric Arylation of Aldehydes. Chem. Eur. J. 2010, 16, 7988-7991. [CrossRef] [PubMed]

27. Da, C.-S.; Wang, J.-R.; Yin, X.-G.; Fan, X.-Y.; Liu, Y.; Yu, S.-L. Highly Catalytic Asymmetric Addition of Deactivated Alkyl Grignard Reagents to Aldehydes. Org. Lett. 2009, 11, 5578-5581. [CrossRef] [PubMed]

28. Muramatsu, Y.; Harada, T. Catalytic Asymmetric Alkylation of Aldehydes with Grignard Reagents. Angew. Chem. Int. Ed. 2008, 47, 1088-1090. [CrossRef] [PubMed]

29. Muramatsu, Y.; Harada, T. Catalytic Asymmetric Aryl Transfer Reactions to Aldehydes with Grignard Reagents as the Aryl Source. Chem. Eur. J. 2008, 14, 10560-10563. [CrossRef] [PubMed]

30. Fernández-Mateos, E.; Maciá, B.; Yus, M. Catalytic Enantioselective Addition of Aryl Grignard Reagents to Ketones. Eur. J. Org. Chem. 2014, 2014, 6519-6526. [CrossRef]

31. Pellissier, H. Enantioselective Titanium-promoted 1,2-additions of Carbon Nucleophiles to Carbonyl Compounds. Tetrahedron 2015, 71, 2487-2524. [CrossRef]

32. Madduri, A.V.R.; Harutyunyan, S.R.; Minnaard, A.J. Asymmetric Copper-Catalyzed Addition of Grignard Reagents to Aryl Alkyl Ketones. Angew. Chem. Int. Ed. 2012, 51, 3164-3167. [CrossRef] [PubMed]

33. Madduri, A.V.R.; Minnaard, A.J.; Harutyunyan, S.R. Copper(I) catalyzed asymmetric 1,2-addition of Grignard Reagents to $\alpha$-methyl Substituted $\alpha, \beta$-unsaturated Ketones. Chem. Commun. 2012, 48, 1478-1480. [CrossRef] [PubMed]

34. Collados, J.F.; Solà, R.; Harutyunyan, S.R.; Maciá, B. Catalytic Synthesis of Enantiopure Chiral Alcohols via Addition of Grignard Reagents to Carbonyl Compounds. ACS Catal. 2016, 6, 1952-1970. [CrossRef]

35. Bieszczad, B.; Gilheany, D.G. Asymmetric Grignard Synthesis of Tertiary Alcohols through Rational Ligand Design. Angew. Chem. Int. Ed. 2017, 56, 4272-4276. [CrossRef] [PubMed]

36. Fernández-Mateos, E.; Maciá, B.; Yus, M. Catalytic Asymmetric Addition of Alkyllithium Reagents to Aromatic Aldehydes. Eur. J. Org. Chem. 2012, 2012, 3732-3736. [CrossRef]

37. Veguillas, M.; Solà, R.; Shaw, L.; Maciá, B. Catalytic Asymmetric Addition of Organolithium Reagents to Aldehydes. Eur. J. Org. Chem. 2016, 9, 1788-1794. [CrossRef]

38. Zong, H.; Huang, H.; Song, L. Catalytic Aasymmetric Addition of Aldehydes Using Organolithium Reagents in the Presence of Commercial Available Chiral Diol Ligands. Tetrahedron Asymmetry 2016, 27, 1069-1074. [CrossRef]

39. Howell, G.P. Asymmetric and Diastereoselective Conjugate Addition Reactions: C-C Bond Formation at Large Scale. Org. Process Res. Dev. 2012, 16, 1258-1272. [CrossRef]

40. Harutyunyan, S.R.; den Hartog, T.; Geurts, K.; Minnaard, A.J.; Feringa, B.L. Catalytic Asymmetric Conjugate Addition and Allylic Alkylation with Grignard Reagents. Chem. Rev. 2008, 108, 2824-2852. [CrossRef] [PubMed]

41. Knochel, P.; Dohle, W.; Gommermann, N.; Kneisel, F.F.; Kopp, F.; Korn, T.; Sapountzis, I.; Vu, V.A. Highly Functionalized Organomagnesium Reagents Prepared through Halogen-Metal Exchange. Angew. Chem. Int. Ed. 2003, 42, 4302-4320. [CrossRef] [PubMed]

42. Negishi, E.I.; Huo, S.; Takahashi, T.; Li, Y.; Dixon, S.; Whitby, R.J.; Hanzawa, Y. Titanium and Zirconium in Organic Synthesis; Marek, I., Ed.; Wiley-VCH: Weinheim, Germany, 2002.

43. Buchwald, S.L.; Nielsen, R.B. Group 4 Metal Complexes of Benzynes, Cycloalkynes, Acyclic Alkynes, and Alkenes. Chem. Rev. 1988, 88, 1047-1058. [CrossRef]

44. Bauer, T. Enantioselective Dialkylzinc-mediated Alkynylation, Arylation and Alkenylation of Carbonyl Groups. Coord. Chem. Rev. 2015, 299, 83-150. [CrossRef] 
45. Negishi, E.-I. Organozirconium Chemistry. In Organometallics in Synthesis: A Manual, 2nd ed.; Schlosser, M., Ed.; John Wiley \& Sons, Inc.: Hoboken, NJ, USA, 2001.

46. Negishi, E.-I.; Takahashi, T. Organozirconium Compounds in Organic Synthesis. Synthesis 1988, 1, 1-19. [CrossRef]

47. Hart, D.W.; Schwartz, J. Hydrozirconation. Organic Synthesis via Organozirconium Intermediates. Synthesis and Rearrangement of Alkylzirconium(IV) Complexes and Their Reaction with Electrophiles. J. Am. Chem. Soc. 1974, 96, 8115-8116. [CrossRef]

48. Negishi, E.-I. A Quarter of a Century of Explorations in Organozirconium Chemistry. Dalton Trans. 2005, 5, 827-848. [CrossRef] [PubMed]

49. Ferreri, C.; Palumbo, G.; Caputo, R. Organotitanium and Organozirconium Reagents in Comprehensive Organic Synthesis, Additions to C-X r-Bonds; Trost, B.M., Ed.; Elsevier Ltd.: Oxford, UK, 1991; Volume 1.

50. Carr, D.B.; Schwartz, J. Preparation of organoaluminum compounds by hydrozirconation-transmetalation. J. Am. Chem. Soc. 1979, 101, 3521-3531. [CrossRef]

51. Venanzi, L.M.; Lehmann, R.; Keil, R.; Lipshutz, B.H. Copper-catalyzed allylic alkylations of alkylzirconium intermediates. Tetrahedron Lett. 1992, 33, 5857-5860. [CrossRef]

52. Babiak, K.A.; Behling, J.R.; Dygos, J.H.; McLaughlin, K.T.; Ng, J.S.; Kalish, V.J.; Kramer, S.W.; Shone, R.L. One-pot synthesis of protected prostaglandins from alkynes and cyclopentenones. In situ generation of higher order cyanocuprates derived from alkenylzirconium intermediates. J. Am. Chem. Soc. 1990, 112, 7441-7442. [CrossRef]

53. Deloux, L.; Skrzypczak-Jankun, E.; Cheesman, B.V.; Srebnik, M.; Sabat, M. First Example of Stable 1,1-Bimetalloalkenes of Boron and Zirconium: Synthesis, Reactivity, X-ray Analysis, and NMR Studies. J. Am. Chem. Soc. 1994, 116, 10302-10303. [CrossRef]

54. Sun, A.; Huang, X. Stereoselective Preparation of $\alpha$-Heteroatom Substituted $\alpha, \beta$-Unsaturated Ketones. Synthesis 2000, 6, 775-777. [CrossRef]

55. Wipf, P.; Xu, W. Transmetalation Reactions of Organozirconocenes: A General, Selective, and Facile Synthesis of Ketones from Acid Chlorides. Synlett 1992, 9, 718-721. [CrossRef]

56. Wipf, P.; Kendall, C. Novel Applications of Alkenyl Zirconocenes. Chem. Eur. J. 2002, 8, 1778-1784. [CrossRef]

57. Negishi, E.; Okukado, N.; King, A.O.; van Horn, D.E.; Spiegel, B.I. Selective carbon-carbon bond formation via transition metal catalysts. 9. Double metal catalysis in the cross-coupling reaction and its application to the stereo- and regioselective synthesis of trisubstituted olefins. J. Am. Chem. Soc. 1978, 100, 2254-2256. [CrossRef]

58. Thompson, C.F.; Jamison, T.F.; Jacobsen, E.N. FR901464: Total Synthesis, Proof of Structure, and Evaluation of Synthetic Analogues. J. Am. Chem. Soc. 2001, 123, 9974-9983. [CrossRef] [PubMed]

59. Suzuki, K. Novel Lewis acid catalysis in organic synthesis. Pure Appl. Chem. 1994, 66, 1557-1564. [CrossRef]

60. Suzuki, K.; Hasegawa, T.; Imai, T.; Maeta, H.; Ohba, S. AgAsF 6 as Safe Alternative to $\mathrm{AgClO}_{4}$ for Generating Cationic Zirconocene Species: Utilities in Lewis Acid-Promoted Selective C-C Bond Forming Reactions. Tetrahedron 1995, 51, 4483-4494. [CrossRef]

61. Maeta, H.; Hashimoto, T.; Hasegawa, T.; Suzuki, K. Grignard-type Addition of Alkenyl- and Alkylzirconocene Chloride to Aldehyde: Remarkable Catalytic Acceleration Effect of $\mathrm{AgClO}_{4}$. Tetrahedron Lett. 1992, 33, 5965-5968. [CrossRef]

62. Zheng, B.; Srebnik, M. 1,2-Addition of Alkyl- and Alkenylzirconocene Chlorides to Aldehydes Accelerated by Catalytic Amounts of $\mathrm{ZnBr}_{2}$ as a Method of Synthesizing Secondary Alcohols, Secondary Allylic Alcohols, and in-Situ Oppenauer-Type Oxidation of the Alcohols to Ketones. J. Org. Chem. 1995, 60, 3278-3279. [CrossRef]

63. Wipf, P.; Xu, W. Preparation of allylic alcohols by alkene transfer from zirconium to zinc. Tetrahedron Lett. 1994, 35, 5197-5200. [CrossRef]

64. Wipf, P.; Xu, W. Allylic Alcohols by Alkene Transfer from Zirconium to Zinc: 1-[(tert-butyldiphenylsilyl)oxy]dec-3-en-5-ol. Org. Synth. 1997, 74, 205.

65. Yamamoto, Y.; Maruyama, K. Crotylzirconium derivatives as a new reagent for the threo selective synthesis of $\beta$-methylhomoallyl alcohols. Tetrahedron Lett. 1981, 22, 2895-2898. [CrossRef]

66. Mashima, K.; Yasuda, H.; Asami, K.; Nakamura, A. Structures of Mono- and Bis(2-butenyl)zirconium complexes in solution and threo selective insertion reaction of aliphatic aldehydes. Chem. Lett. 1983, 12, 219-222. [CrossRef] 
67. Yamamoto, Y.; Saito, Y.; Maruyama, K. The influence of (organo)metallics "metal-tuning" on stereo- and regio-chemical convergence in reactions of allylic carbanions with aldehydes. J. Organomet. Chem. 1985, 292, 311-318. [CrossRef]

68. Fan, G.; Xie, X.; Liu, Y.; Li, Y. Unusual Regioselectivity in the Aldehyde Addition Reactions of Allenyl/Propargyl Zirconium Complexes Derived from $\gamma$-(2-Pyridyl)propargyl Ethers: Synthesis of Multisubstituted $\alpha$-Hydroxyallenes. Organometallics 2013, 32, 1636-1642. [CrossRef]

69. Weidman, B.; Maycock, C.D.; Seebach, D. Alkyl-, Aryl-, Vinyl-, and Heterosubstituted Organozirconium Compounds. -Selective nucleophiles of low basicity. Preliminary communication. Helv. Chim. Acta 1981, 64, 1552-1557. [CrossRef]

70. Weidman, B.; Seebach, D. Organometallic Compounds of Titanium and Zirconium as Selective Nucleophilic Reagents in Organic Synthesis. Angew. Chem. Int. Ed. 1983, 22, 31-45. [CrossRef]

71. Loots, M.J.; Schwartz, J. Nickel-catalyzed conjugate addition of zirconium alkenyls to $\alpha, \beta$-Unsaturated Ketones. J. Am. Chem. Soc. 1977, 99, 8045-8046. [CrossRef]

72. Lipshutz, B.H.; Ellsworth, E.L. Hydrozirconation-transmetalation. A mild, direct route to higher order vinylic cuprates from monosubstituted acetylenes. J. Am. Chem. Soc. 1990, 112, 7440-7441. [CrossRef]

73. Wipf, P.; Smitrovich, J.H. Transmetalation reactions of alkylzirconocenes: Copper-catalyzed conjugate addition to enones. J. Org. Chem. 1991, 56, 6494-6496. [CrossRef]

74. Wipf, P.; Xu, W.J.; Smitrovich, J.H.; Lehmann, R.; Venanzi, L.M. Copper-catalyzed conjugate additions of organozirconocenes. Synthetic and mechanistic studies. Tetrahedron 1994, 50, 1935-1954. [CrossRef]

75. Wipf, P.; Xu, W. Organozirconocenes in organic synthesis: Tandem epoxide rearrangement-carbonyl addition. J. Org. Chem. 1993, 58, 825-826. [CrossRef]

76. Negishi, E.; Swanson, D.R.; Miller, S.R. One-pot conversion of alkynes and alkenes into one-carbon homologated aldehydes via hydrozirconation-isocyanide insertion-hydrolysis. Tetrahedron Lett. 1988, 29, 1631-1634. [CrossRef]

77. Wipf, P.; Stephenson, C.R. Dimethylzinc-Mediated Addition of Alkenylzirconocenes to $\alpha$-Keto and $\alpha$-Imino Esters. Org. Lett. 2003, 5, 2449-2452. [CrossRef] [PubMed]

78. Wipf, P.; Takahashi, H. Copper(I)-catalysed asymmetric conjugate addition of organozirconocenes to $N$-acyl oxazolidinones. Chem. Commun. 1996, 23, 2675-2676. [CrossRef]

79. Chavez, D.E.; Jacobsen, E.N. Total Synthesis of Fostriecin (CI-920). Angew. Chem. Int. Ed. 2001, 40, 3667-3670. [CrossRef]

80. Lou, S.; Fu, G.C. Enantioselective Alkenylation via Nickel-Catalyzed Cross-Coupling with Organozirconium Reagents. J. Am. Chem. Soc. 2010, 132, 5010-5011. [CrossRef] [PubMed]

81. Westmeier, J.; Pfaff, C.; Siewert, J.; von Zezschwitz, P. First Tandem Asymmetric Conjugate Addition of Alkenyl Nucleophiles and Silyl Trapping of the Intermediate Enolates. Adv. Synth. Catal. 2013, 355, 2651-2658. [CrossRef]

82. Roth, P.M.C.; Fletcher, S.P. Enantioselective Copper(I)-Phosphoramidite Catalyzed Addition of Alkylzirconium Species to Acyclic Enones. Org. Lett. 2015, 17, 912-915. [CrossRef] [PubMed]

83. Sidera, M.; Roth, P.M.C.; Maksymowicz, R.M.; Fletcher, S.P. Formation of Quaternary Centers by Copper-Catalyzed Asymmetric Conjugate Addition of Alkylzirconium Reagents. Angew. Chem. Int. Ed. 2013, 52, 7995-7999. [CrossRef] [PubMed]

84. Roth, P.M.C.; Sidera, M.; Maksymowicz, R.M.; Fletcher, S.P. Copper-catalyzed asymmetric conjugate addition of alkylzirconium reagents to cyclic enones to form quaternary centers. Nat. Protoc. 2013, 9, 104-111. [CrossRef] [PubMed]

85. Rideau, E.; Mäsing, F.; Fletcher, S.P. Asymmetric Conjugate Addition of Alkylzirconocenes to Cyclopent-4-ene-1,3-dione Monoacetals. Synthesis 2015, 47, 2217-2222.

86. Maksymowicz, R.M.; Roth, P.M.C.; Fletcher, S.P. Catalytic asymmetric carbon-carbon bond formation using alkenes as alkylmetal equivalents. Nat. Chem. 2012, 4, 649-654. [CrossRef] [PubMed]

87. Maksymowicz, R.M.; Sidera, M.; Roth, P.M.C.; Fletcher, S.P. A Convenient Catalytic Asymmetric Conjugate Addition Reaction to Enones Using Alkylzirconium Reagents. Synthesis 2013, 45, 2662-2668. [CrossRef]

88. Maciver, E.E.; Maksymowicz, R.M.; Wilkinson, N.; Roth, P.M.C.; Fletcher, S.P. Asymmetric Conjugate Addition of Alkylzirconium Reagents to $\alpha, \beta$-Unsaturated Lactones. Org. Lett. 2014, 16, 3288-3291. [CrossRef] [PubMed] 
89. Caprioglio, D.; Fletcher, S.P. An alternative synthesis of the breast cancer drug fulvestrant $\left(\right.$ Faslodex $\left.^{\circledR}\right)$ : Catalyst control over C-C bond formation. Chem. Commun. 2015, 51, 14866-14868. [CrossRef] [PubMed]

90. Maksymowicz, R.M.; Roth, P.M.C.; Thompson, A.L.; Fletcher, S.P. Hydrometallation-asymmetric conjugate addition: Application to complex molecule synthesis. Chem. Commun. 2013, 49, 4211-4213. [CrossRef] [PubMed]

91. Mola, L.; Sidera, M.; Fletcher, S.P. Asymmetric Remote C-H Functionalization: Use of Internal Olefins in Tandem Hydrometallation-Isomerization-Asymmetric Conjugate Addition Sequences. Aust. J. Chem. 2015, 68, 401-403. [CrossRef]

92. Garrec, K.; Fletcher, S.P. $\mathrm{Cp}_{2} \mathrm{ZrMeCl}$ : A Reagent for Asymmetric Methyl Addition. Org. Lett. 2016, 18, 3814-3817. [CrossRef] [PubMed]

93. Wipf, P.; Jayasuriya, N.; Ribe, S. On the role of chiral catalysts in the alkenyl zirconocene/zinc addition to aldehydes: A study of ligand loading and asymmetric amplification. Chirality 2003, 15, 208-212. [CrossRef] [PubMed]

94. Wipf, P.; Ribe, S. Zirconocene-Zinc Transmetalation and in-Situ Catalytic Asymmetric Addition to Aldehydes. J. Org. Chem. 1998, 63, 6454-6455. [CrossRef]

95. Li, H.; Walsh, P.J. Catalytic Asymmetric Vinylation and Dienylation of Ketones. J. Am. Chem. Soc. 2005, 127, 8355-8361. [CrossRef] [PubMed]

96. $\mathrm{Pu}, \mathrm{L}$. Asymmetric Functional Organozinc Additions to Aldehydes Catalyzed by 1,1'-Bi-2-naphthols (BINOLs). Acc. Chem. Res. 2014, 47, 1523-1535. [CrossRef] [PubMed]

97. Schwartz, J.; Labinger, J.A. Hydrozirconation: A New Transition Metal Reagent for Organic Synthesis. Angew. Chem. Int. Ed. Engl. 1976, 15, 333-340. [CrossRef]

98. Buchwald, S.L.; LaMaire, S.J.; Nielsen, R.B. Schwartz's Reagent. Org. Synth. 1993, 71, 77-82.

99. Wipf, P.; Jahn, H. Synthetic applications of organochlorozirconocene complexes. Tetrahedron 1996, 52, 12853-12910. [CrossRef]

100. Patai, S. The Chemistry of the Double Bonded Functional Groups; Wiley: Chichester, UK, 1997.

101. Uhlig, E.; Bürglen, B.; Krüger, C.; Betz, P. Die reaktivitätsabstufung von trimethylsiloxygruppen gegenüber dem Hydrozirconierungsreagenz $\mathrm{Cp}_{2} \mathrm{Zr}(\mathrm{H}) \mathrm{Cl}$. J. Organomet. Chem. 1990, 382, 77-88. [CrossRef]

102. Gao, G.; Gu, F.-L.; Jiang, J.-X.; Jiang, K.; Sheng, C.-Q.; Lai, G.-Q.; Xu, L.-W. Neighboring Lithium-Assisted [1,2]-Wittig Rearrangement: Practical Access to Diarylmethanol-Based 1,4-Diols and Optically Active BINOL Derivatives with Axial and sp ${ }^{3}$-Central Chirality. Chem. Eur. J. 2011, 17, 2698-2703. [CrossRef] [PubMed]

103. Kiyooka, S.-I.; Tsutsui, T.; Kira, T. Complete asymmetric induction in [1,2]-wittig rearrangement of a system involving a binaphthol moiety. Tetrahedron Lett. 1996, 37, 8903-8904. [CrossRef]

104. Gao, G.; Bai, X.-F.; Yang, H.-M.; Jiang, J.-X.; Lai, G.-Q.; Xu, L.W. Ar-BINMOLs with Axial and sp ${ }^{3}$ Central Chirality-Characterization, Chiroptical Properties, and Application in Asymmetric Catalysis. Eur. J. Org. Chem. 2011, 2011, 5039-5046. [CrossRef]

105. Xu, Z.; Xu, L.-W. Development of Ar-BINMOL-Derived Atropisomeric Ligands with Matched Axial and $\mathrm{sp}^{3}$ Central Chirality for Catalytic Asymmetric Transformations. Chem. Rec. 2015, 15, 925-948. [CrossRef] [PubMed]

106. Panek, J.S.; Hu, T. Asymmetric Synthesis of $(2 S, 3 S, 8 S, 9 S)-N$-Boc ADDA: Application of a Palladium(0)-Catalyzed Cross-Coupling Reaction of Trisubstituted Olefins. J. Org. Chem. 1997, 62, 4914-4915. [CrossRef]

107. Ho, T.; Panek, J.S. Total Synthesis of (-)-Motuporin. J. Org. Chem. 1999, 64, 3000-3001.

108. Drouet, K.E.; Theodorakis, E.A. Enantioselective Total Synthesis of Reveromycin B. J. Am. Chem. Soc. 1999, 121, 456-457. [CrossRef]

109. Muller, B.; Ruf, M.; Vahrenkamp, H. On the Nature of Zinc Chloride-Aldehyde Interactions. Angew. Chem. Int. Ed. Engl. 1994, 33, 2089-2090. [CrossRef]

110. Jordan, R.F. Chemistry of Cationic Dicyclopentadienyl Group 4 Metal-Alky I Complexes. Adv. Organomet. Chem. 1991, 32, 325-387.

111. Veguillas, M.; Solà, R.; Fernández-Ibáñez, M.A.; Maciá, B. Catalytic enantioselective addition of methyltriisopropoxititanium to aldehydes. Tetrahedron Asymmetry 2016, 27, 643-648. [CrossRef]

112. Boivin, T.L.B. Synthetic routes to tetrahydrofuran, tetrahydropyran, and spiroketal units of polyether antibiotics and a survey of spiroketals of other natural products. Tetrahedron 1987, 43, 3309-3362. [CrossRef]

113. Cradillo, G.; Orena, M. Stereocontrolled cyclofunctionalizations of double bonds through heterocyclic intermediates. Tetrahedron 1990, 46, 3321-3408. [CrossRef] 
114. Kotsuki, H. Bicyclic Ketals: Versatile Intermediates for the Stereocontrolled Construction of Cyclic Ether Derivatives. Synlett 1992, 1992, 97-106. [CrossRef]

115. Bartlett, P.A. Stereocontrol in the synthesis of acyclic systems: Applications to natural product synthesis. Tetrahedron 1980, 36, 2-72. [CrossRef]

116. Elliott, M.C.; Williams, E. Saturated oxygen heterocycles. J. Chem. Soc. Perkin Trans. 2001, 1, $2303-2340$. [CrossRef]

117. Narula, A.P.S. The Search for New Fragrance Ingredients for Functional Perfumery. Chem. Biodivers. 2004, 1, 1992-2000. [CrossRef] [PubMed]

118. Loman, J.J.; Carnaghan, E.R.; Hamlin, T.A.; Ovian, J.M.; Kelly, C.B.; Mercadante, M.A.; Leadbeater, N.E. A combined computational and experimental investigation of the oxidative ring-opening of cyclic ethers by oxoammonium cations. Org. Biomol. Chem. 2016, 14, 3883-3888. [CrossRef] [PubMed]

119. Chan, T.H.; Pellon, P. Chiral organosilicon compounds in synthesis. Highly enantioselective synthesis of arylcarbinols. J. Am. Chem. Soc. 1989, 111, 8737-8738. [CrossRef]

Sample Availability: Samples of the compound 3 are available from the authors.

(C) 2018 by the authors. Licensee MDPI, Basel, Switzerland. This article is an open access article distributed under the terms and conditions of the Creative Commons Attribution (CC BY) license (http:/ / creativecommons.org/licenses/by/4.0/). 